\title{
Stability and trans influence in fluorinated gold(I) coordination compounds
}

\author{
Guillermo Moreno-Alcántar, ${ }^{[a] \star}$ Hugo Hernández-Toledo, ${ }^{ \pm[a] J o s e ́ ~ M a n u e l ~ G u e v a r a-V e l a, ~}{ }^{\ddagger[b]}$ Tomás \\ Rocha-Rinza, ${ }^{[c]}$ Ángel Martín Pendás, ${ }^{[b]}$ Marcos Flores-Álamo, ${ }^{[a]}$ and Hugo Torrens ${ }^{[a] *}$
}

\begin{abstract}
We examined the Au-P and Au-X chemical bonding scenario throughout the series of compounds of the general formula $\left[A u X\left(L_{P}\right)\right]$ wherein $L_{P}$ is triphenylphosphine or a fluorinated phosphine $\left(\mathrm{PPh}_{\mathrm{F}}=\mathrm{P}\left(\mathrm{C}_{6} \mathrm{H}_{5}\right)_{2}\left(\mathrm{C}_{6} \mathrm{~F}_{5}\right) \mathbf{1}, \mathrm{P}\left(\mathrm{C}_{6} \mathrm{H}_{5}\right)\left(\mathrm{C}_{6} \mathrm{~F}_{5}\right)_{2} 2\right.$ and $\left.\mathrm{P}\left(\mathrm{C}_{6} \mathrm{~F}_{5}\right)_{3} 3\right)$ and $\mathrm{X}$ is chloride or a fluorinated thiolate $\left(\mathrm{SR}_{\mathrm{F}}=\mathrm{SCF}_{3} \mathbf{a}, \mathrm{SCH}_{2} \mathrm{CF}_{3} \mathbf{b}, \mathrm{SC}_{6} \mathrm{~F}_{5} \mathbf{C}\right.$ $\left.\mathrm{SC}_{6} \mathrm{~F}_{4}\left(\mathrm{CF}_{3}\right)-4 \mathrm{~d}\right)$. We found that the increase of the fluorination degree or the replacement of $\mathrm{Cl}^{-}$by a $\mathrm{SR}_{\mathrm{F}}$ ligand decreases the stability of the compound. Furthermore, this substitution shifts the ${ }^{31} \mathrm{P}-\mathrm{NMR}$ signals to low field which indicates differences in the electronegativity of the phosphorus due to the distinct trans influences of the $\mathrm{Cl}^{-}$and $\mathrm{SR}_{\mathrm{F}}$ species. These effects correlate with the charge of the gold atom coordinated to phosphorus. Our investigation shows the high potential of fluorination as a strategy for the modulation of the properties of gold compounds, e.g. in catalysis, and the applicability of quantum chemical topology studies in the explanation of these features.
\end{abstract}

\section{Introduction}

Gold(I) tris(pentafluorophenyl)phosphine complexes have been extensively used as catalysts in organic conversions ${ }^{[1-8]}$. In contrast, the applications and properties of the related partially fluorinated phosphines have been relatively unexplored. ${ }^{[9-11]}$ This circumstance occurs despite the interesting opportunities for the analysis of the ligand-induced influences over the catalytic center that these compounds offer.

One of these effects is the trans influence, i.e., the set of modifications that one ligand induces over the metal bond to the ligand in its trans position, which concerns the stability, reactivity and properties of coordination compounds ${ }^{[12]}$. The understanding and use of this effect is one of the pillars for the improvement of synthetical and predictive capabilities of inorganic chemists. Particularly, the trans influence, can be studied in different ways $^{[13-17]}$. If the atom of the ligand interacting directly with the metal center is an NMR active species, this technique becomes a powerful tool to get insights into this phenomenon. ${ }^{[18-20]}$ Because

[a] Prof., H. Torrens, G. Moreno-Alcántar, H. Hernández-Toledo, Dr. M. Flores-Álamo

Faculty of Chemistry

Universidad Nacional Autónoma de México

Ciudad Universitaria, Coyoacán, México, 04510.

E-mail: Igma@comunidad.unam.mx, torrens@unam.mx.

[b] Prof., A. Martín Pendás, J. M. Guevara-Vela

Department of Physical and Analytical Chemistry

Universidad de Oviedo

Julián Clavería 8, Oviedo, Spain. E-33006

[c] Prof., T. Rocha-Rinza,

Institute of Chemistry

Universidad Nacional Autónoma de México

Ciudad Universitaria, Coyoacán, México, 04510.

Supporting information for this article is given via a link at the end of the document. CCDC references for X-ray structures: 1587377 1587380
gold(I) coordination compounds commonly exhibit linear geometries, they are ideal systems to study the trans influences among different ligands ${ }^{[20,21]}$.

Given this background, we investigated the trans influence that anionic ligands exert over phosphorus atoms in gold phosphine complexes. More specifically, we synthesized and characterized the three fluorophosphine gold $(\mathrm{I})$ derivatives $\left[\mathrm{AuCl}\left(\mathrm{PPh}_{\mathrm{F}}\right)\right]$ with $\mathrm{PPh}_{\mathrm{F}}=\mathrm{P}\left(\mathrm{C}_{6} \mathrm{H}_{5}\right)_{2}\left(\mathrm{C}_{6} \mathrm{~F}_{5}\right) \mathbf{1}, \mathrm{P}\left(\mathrm{C}_{6} \mathrm{H}_{5}\right)\left(\mathrm{C}_{6} \mathrm{~F}_{5}\right)_{2} 2$ and $\mathrm{P}\left(\mathrm{C}_{6} \mathrm{~F}_{5}\right)_{3} 3$. We also obtained the previously unreported crystal $\mathrm{X}$ ray structures of compounds 1 and 2 . In addition, we prepared 8 new derivatives via the substitution of chloride in $\mathbf{1}$ and $\mathbf{2}$ with fluorinated thiolates, yielding the compounds with the general formula $\left[\mathrm{Au}\left(\mathrm{SR}_{\mathrm{F}}\right)\left(\mathrm{PPh}_{\mathrm{F}}\right)\right]$ (where $\mathrm{SR}_{\mathrm{F}}=\mathrm{SCF}_{3} \mathbf{a}, \mathrm{SCH}_{2} \mathrm{CF}_{3} \mathbf{b}$, $\left.\mathrm{SC}_{6} \mathrm{~F}_{5} \mathrm{c}, \mathrm{SC}_{6} \mathrm{~F}_{4}\left(\mathrm{CF}_{3}\right)-4 \mathrm{~d}\right)$. We report the crystal structures of compounds $\left[\mathrm{AuSCF}_{3}\left(\mathrm{P}\left(\mathrm{C}_{6} \mathrm{H}_{5}\right)_{2}\left(\mathrm{C}_{6} \mathrm{~F}_{5}\right)\right)\right]$ 1a and $\left[\mathrm{AuSCH}_{2} \mathrm{CF}_{3}\right.$ $\left.\left(\mathrm{P}\left(\mathrm{C}_{6} \mathrm{H}_{5}\right)_{2}\left(\mathrm{C}_{6} \mathrm{~F}_{5}\right)\right)\right] \mathbf{1 b}$ as well. We also synthesized the analogous derivatives of triphenylphosphine $\left[\mathrm{AuSR}_{\mathrm{F}}\left(\mathrm{PPh}_{3}\right)\right]$.

Later, we studied the relative stability of the three fluorinated-phosphine gold $(\mathrm{I})$ chloride derivatives (1, 2 and 3 ) by ${ }^{31} \mathrm{P}-\mathrm{NMR}$. Finally, we performed electronic structure and quantum chemical calculations to investigate the chemical bonding scenario within these systems. Overall, our results show how the techniques employed herein can prove useful in the study of the trans effect in gold(I) phosphine complexes.

\section{Results and Discussion}

Chloro(fluorophosphine)gold(I) compounds [AuCl( $\left.\left.\mathrm{PPh}_{\mathrm{F}}\right)\right]$ were prepared by the reaction of chloro(tetrahydrothiophene)gold(I) with the corresponding fluorinated phosphine. The synthesis and experimental handling of the thiolate derivatives of compounds $\mathbf{1}$, $\mathbf{2}$ and $\mathbf{3}$ show that compounds $\mathbf{1 x}$ are the most stable as they can be further characterized and crystallized. Compounds $\mathbf{2 x}$ are less stable and even if they can be characterized, their short lifetimes and low stability did not allow us to obtain crystals. Finally, thiolate derivatives of $\mathbf{3}$ could not be identified. To further examine the relative stability of the chloro(fluorophosphine)gold(I) compounds (1, 2 and 3), we performed ligand substitution reactions starting from compound 3. Figure 1 shows the ${ }^{31} \mathrm{P}-\mathrm{NMR}$ spectra of the reaction system in chloroform-d. The uppermost spectrum corresponds to a solution of compound $3(-35.4 \mathrm{ppm})$. The addition of a stoichiometric amount of $\mathrm{P}\left(\mathrm{C}_{6} \mathrm{H}_{5}\right)\left(\mathrm{C}_{6} \mathrm{~F}_{5}\right)_{2}$ to this solution yields $\mathrm{P}\left(\mathrm{C}_{6} \mathrm{~F}_{5}\right)_{3}(-76.5 \mathrm{ppm})$ and forms compound 2 (-8.5 ppm). Further addition of $\mathrm{P}\left(\mathrm{C}_{6} \mathrm{H}_{5}\right)_{2}\left(\mathrm{C}_{6} \mathrm{~F}_{5}\right)$ to the system results in the production of $\mathrm{P}\left(\mathrm{C}_{6} \mathrm{H}_{5}\right)\left(\mathrm{C}_{6} \mathrm{~F}_{5}\right)_{2}(-48.1 \mathrm{ppm})$ and compound 1 (12.4 ppm). Finally, when we added triphenylphosphine to the last-mentioned solution, we detected the formation of $\left[\mathrm{AuCl}\left(\mathrm{PPh}_{3}\right)\right](31.1 \mathrm{ppm})$ and $\mathrm{P}\left(\mathrm{C}_{6} \mathrm{H}_{5}\right)_{2}\left(\mathrm{C}_{6} \mathrm{~F}_{5}\right)(-25.2 \mathrm{ppm})$. The coordination of phosphorus to the gold center unshields the ${ }^{31} \mathrm{P}$ nucleus resulting in a signal displaced to low field as compared to the free phosphine, this seems to be a general behavior in 


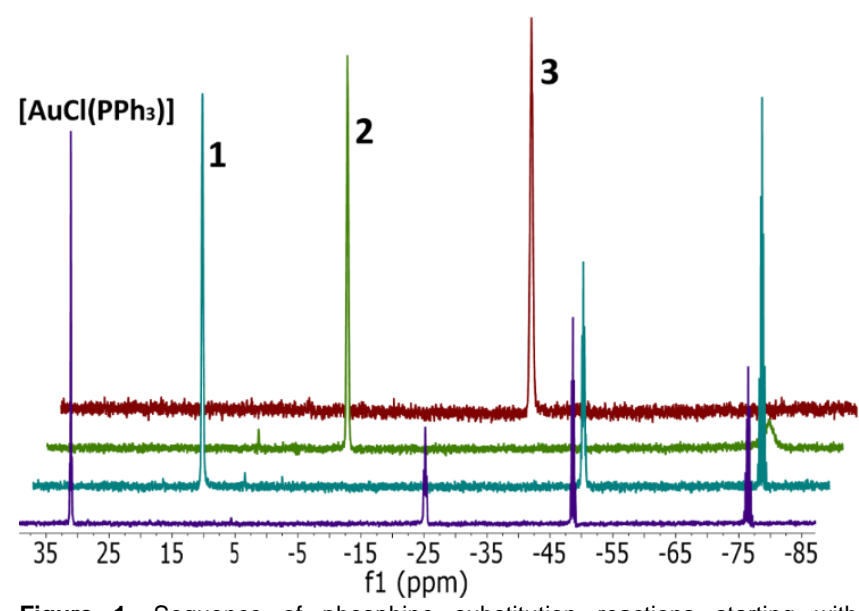

Figure 1. Sequence of phosphine substitution reactions starting with compound 3 (top) monitored by ${ }^{31} \mathrm{P}-\mathrm{NMR}$ in $\mathrm{CDCl} 3$.

phosphinegold(I) complexes ${ }^{[22]}$. We performed geometry optimizations of the systems of interest in gas phase and in solution with density functional theory (see the Computational details section). The results indicate that the process of ligand exchange is thermodynamically favored in both phases, and therefore we refer only to the results computed in solution phase in the rest of the paper. Scheme 1 reports the calculated $\Delta G$ for the three successive substitution reactions. Additionally, Figure 2 shows a correlation between cumulative $\Delta G$ values and the ${ }^{31} \mathrm{P}$ NMR chemical shift of the product. We note that shielded phosphorus atoms give place to thermodynamically less stable

Scheme 1. Calculated $\Delta G$ values $(\mathrm{kcal} / \mathrm{mol})$ for the consecutive phosphine substitution reactions.

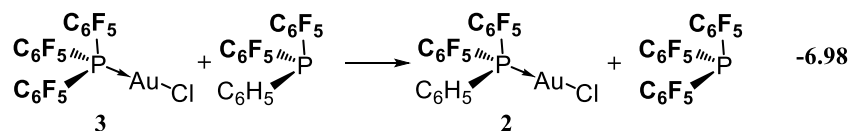

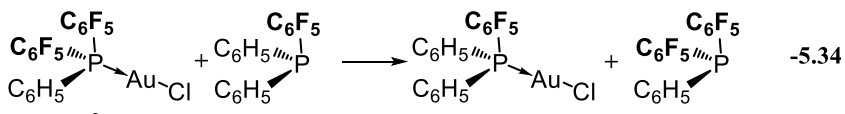$$
1
$$
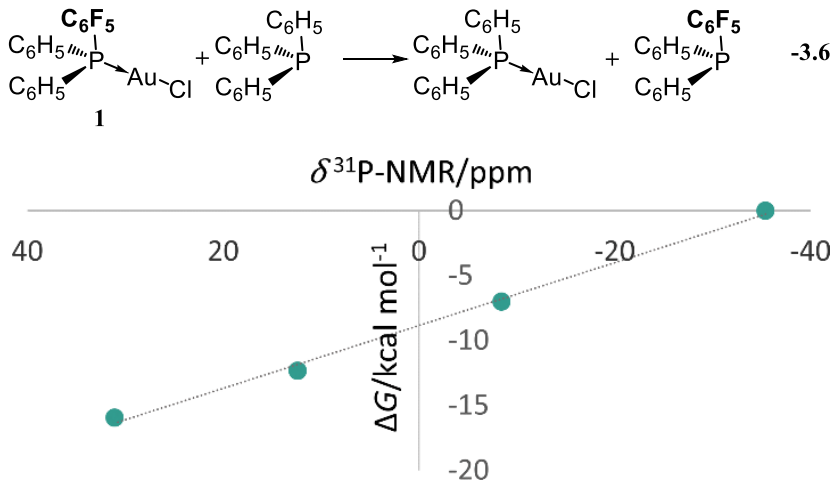

Figure 2. Correlation between the cumulative change in Gibbs free energy associated to the phosphine substitution reactions of Scheme 1 and the ${ }^{31} \mathrm{P}$ NMR shift of the product. $\left(\mathrm{CDCl}_{3}\right)$. compounds than unshielded $\mathrm{P}$ nuclei. this observed trend in stability is consistent with that observed in TGA results (FigureS13-S16 in the ESI).

The shielding of the ${ }^{31} \mathrm{P}$ nuclei is directly related to the equilibrium electronegativity of the atom in the molecule ${ }^{[23]}$, a more electronegative phosphorus center is expected to be a worse $\sigma$ donor ligand and vice versa, then the shielding on the phosphine $\mathrm{P}$ atom will be related to the strength of the Au-P bond to be formed. The weaker the gold phosphorus bond, the easier the substitution of the ligand, as observed for the largest values of $\Delta G$ for the substitutions reactions presented in Scheme 1. Moreover, the coordination of the phosphine to gold also increases the shielding of $\mathrm{P}$, and thereby its equilibrium electronegativity, as discussed below.

Figure 3 shows the crystal structures of compounds 1, 2 and 3 . The three systems show similar conformations. The gold coordination geometry is almost linear and bond angles and distances are similar in the three monomeric units. Selected bond lengths and angles are shown in Table 1. P-Au and Au-C distances are affected by the changes in the fluorination of the phosphine ligand. Both bonds show the same trend with respect to the degree of fluorination of the ligand, i. e. the most fluorinated phosphine results in the shortest bonds. Whilst these changes are rather subtle for the Au-P bond distances, the corresponding variations for the $\mathrm{Au}-\mathrm{Cl}$ interaction are more pronounced. These results evidence the different trans influence of the phosphines considered in this investigation. The shortest $\mathrm{Au}-\mathrm{Cl}$ bond corresponds to the most fluorinated phosphine. This effect could result from the diminution of electron density at the Au center indicated by its QTAIM charge (Table 2). This rise in $q_{\mathrm{Au}}$ increases gold electrophilicity and it causes that the metallic center attracts electron density from the chlorine atom more efficiently.

Table 1. Experimental and calculated $\mathrm{Au}-\mathrm{P}$ and $\mathrm{Au}-\mathrm{Cl}$ bond distances along with the $\mathrm{P}-\mathrm{Au}-\mathrm{Cl}$ bond angle for compounds 1-3 and $\left[\mathrm{AuCl}\left(\mathrm{PPh}_{3}\right)\right]$.

\begin{tabular}{ccccc}
\hline Compound & & $\boldsymbol{D}_{\text {Au-P }}$ & $\boldsymbol{D}_{\text {Au-Cl }}$ & $\boldsymbol{\theta}_{\mathbf{P}-\mathbf{A u}-\mathbf{C l}}$ \\
\hline \multirow{2}{*}[\mathbf{AuCl}(\mathbf{PPh}_{\mathbf{3}})]{$^{\mathbf{a}}$} & Exp. & $2.228(1)$ & $2.288(1)$ & 179.17 \\
& Calc. & 2.2356 & 2.3069 & 179.79 \\
\hline \multirow{2}{*}{$\mathbf{1}$} & Exp. & $2.224(1)$ & $2.278(1)$ & 178.48 \\
& & $2.229(1)$ & $2.281(1)$ & \\
& Calc. & 2.2325 & 2.3014 & 179.47 \\
\hline \multirow{2}{*}{$\mathbf{2}$} & Exp. & $2.222(1)$ & $2.276(1)$ & 173.75 \\
& & $2.227(1)$ & $2.280(1)$ & 174.83 \\
& Calc. & 2.2277 & 2.2890 & 177.83 \\
\hline \multirow{2}{*}{$\mathbf{3}^{\mathbf{b}}$} & & $2.206(1)$ & $2.269(1)$ & 172.69 \\
& Exp. & $2.215(1)$ & $2.271(1)$ & 176.54 \\
& Calc. & 2.2277 & 2.2890 & 179.88
\end{tabular}

[a] Experimental distances reported by Dunstan, $2014^{[24]}$ and [b] Chen, $2013^{[25]}$.
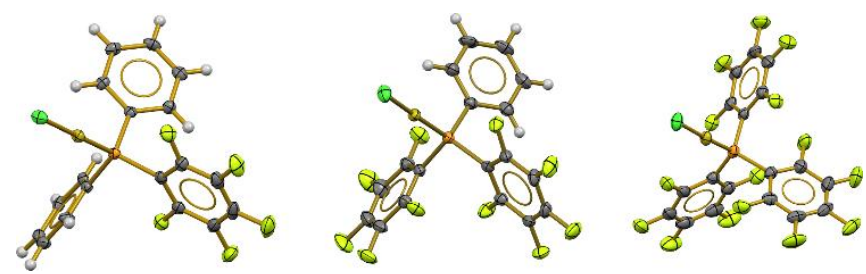

Figure 3. ORTEP diagrams at $50 \%$ probability level of the $\mathrm{X}$-ray structures of compounds 1-3. Colour code: orange, P; golden, Au; green, $\mathrm{Cl}$; grey, C; white, $\mathrm{H}$. 


\begin{tabular}{|c|c|c|c|c|c|c|c|c|c|}
\hline Compound & DI & $\rho\left(\mathbf{r}_{\mathrm{BCP}}\right)$ & $\nabla^{2} \rho\left(\mathbf{r}_{\mathrm{BCP}}\right)$ & $\varepsilon$ & $V$ & $G$ & $|V| / G$ & $q_{\mathrm{Au}}$ & $\delta^{31} \mathrm{P}(\mathrm{ppm})$ \\
\hline$[\mathrm{AuCl}(\mathrm{PPh} 3)]$ & 1.0597 & 0.1280 & 0.0291 & 0.0006 & -0.1500 & 0.0787 & 1.91 & 0.0239 & $31.1^{\mathrm{a}}$ \\
\hline 1 & 1.0586 & 0.1284 & 0.0379 & 0.0051 & -0.1526 & 0.0810 & 1.88 & 0.0538 & 12.4 \\
\hline 2 & 1.0614 & 0.1287 & 0.0488 & 0.0136 & -0.1557 & 0.0839 & 1.86 & 0.0923 & -8.5 \\
\hline 3 & 1.0497 & 0.1284 & 0.0591 & 0.0002 & -0.1572 & 0.0860 & 1.83 & 0.1289 & -35.4 \\
\hline$\left[\mathrm{Au}\left(\mathrm{SCF}_{3}\right)\left(\mathrm{PPh}_{3}\right)\right]$ & 0.9996 & 0.1211 & 0.0455 & 0.0369 & -0.1386 & 0.0750 & 1.85 & -0.0294 & 38.1 \\
\hline $1 \mathbf{a}$ & 0.9965 & 0.1212 & 0.0544 & 0.0440 & -0.1407 & 0.0771 & 1.82 & -0.0040 & 15.7 \\
\hline $\mathbf{2 a}$ & 0.9944 & 0.1210 & 0.0647 & 0.0529 & -0.1428 & 0.0795 & 1.80 & 0.0282 & 1.3 \\
\hline $3 \mathbf{a}$ & 0.9976 & 0.1213 & 0.0749 & 0.0408 & -0.1457 & 0.0822 & 1.77 & 0.0590 & $*$ \\
\hline$\left[\mathrm{Au}\left(\mathrm{SCH}_{2} \mathrm{CF}_{3}\right)\left(\mathrm{PPh}_{3}\right)\right]$ & 0.9966 & 0.1202 & 0.0546 & 0.0415 & -0.1462 & 0.0762 & 1.92 & -0.0588 & 35.94 \\
\hline $1 \mathbf{b}$ & 0.9960 & 0.1204 & 0.0627 & 0.0442 & -0.1431 & 0.0784 & 1.83 & -0.0343 & 25.86 \\
\hline $2 b$ & 0.9941 & 0.1202 & 0.0728 & 0.0582 & -0.1410 & 0.0806 & 1.75 & -0.0023 & 7.82 \\
\hline 3b & 0.9983 & 0.1206 & 0.0822 & 0.0335 & -0.1387 & 0.0834 & 1.66 & 0.0298 & $*$ \\
\hline$\left[\mathrm{Au}\left(\mathrm{SC}_{6} \mathrm{~F}_{5}\right)\left(\mathrm{PPh}_{3}\right)\right]$ & 1.0072 & 0.1221 & 0.0449 & 0.0365 & -0.1411 & 0.0761 & 1.85 & -0.0474 & 35.00 \\
\hline $1 \mathrm{c}$ & 1.0011 & 0.1216 & 0.0553 & 0.0540 & -0.1429 & 0.0783 & 1.83 & -0.0128 & 20.40 \\
\hline $2 c$ & 1.0037 & 0.1218 & 0.0651 & 0.0540 & -0.1455 & 0.0809 & 1.80 & 0.0196 & -3.28 \\
\hline $3 c$ & 1.0002 & 0.1215 & 0.0769 & 0.0301 & -0.1468 & 0.0830 & 1.77 & 0.0485 & $*$ \\
\hline$\left[\mathrm{Au}\left(\mathrm{SC}_{6} \mathrm{~F}_{4}\left(\mathrm{CF}_{3}\right)-4\right)\left(\mathrm{PPh}_{3}\right)\right]$ & 1.0068 & 0.1221 & 0.0428 & 0.0366 & -0.1408 & 0.0758 & 1.86 & -0.0347 & 35.09 \\
\hline $1 d$ & 1.0048 & 0.1223 & 0.0516 & 0.0324 & -0.1429 & 0.0779 & 1.83 & -0.0110 & 17.95 \\
\hline $2 d$ & 1.0028 & 0.1219 & 0.0632 & 0.0535 & -0.1453 & 0.0806 & 1.80 & 0.0322 & -5.68 \\
\hline $3 d$ & 1.0013 & 0.1218 & 0.0743 & 0.0302 & -0.1467 & 0.0826 & 1.78 & 0.0619 & $*$ \\
\hline
\end{tabular}

*Compounds 3a-d have not been isolated. [a] Dunstan,2014 ${ }^{[24]}$

The slight variations in the Au-P distances are baffling. The successive changes in Gibbs free energy in Scheme 1 indicate that the most fluorinated phosphine is associated with the weakest $\mathrm{Au}-\mathrm{P}$ bond. But, in contrast with the common assumption about the relationship between bond length and bond strength (first suggested by Pauling) ${ }^{[26]}$, the Au-P distance does not increase as the Au-P bond becomes weaker. Furthermore the widespread notion that $\pi$-acceptor ligands tend to make stronger bonds ${ }^{[27]}$ contrasts with the preference of the gold atom for the worst $\pi$-acceptor of the group of ligands. A detailed analysis of systems $\mathbf{1}$ to $\mathbf{3}$ using the QTAIM (Table 2) gives valuable insights about the features of the Au-P chemical bonds. First, the value of the electronic density at the Bond Critical Point (BCP) $\rho\left(\mathbf{r}_{\mathrm{BCP}}\right)$ is essentially equal for the four analyzed compounds. Second, the delocalization Index (DI), which is a measure of the number of electron pairs shared by two atoms, decreases slightly with fluorination, indicating a small reduction of the degree of covalency of the bond. Third, $\nabla^{2} \rho\left(\mathbf{r}_{\mathrm{BCP}}\right)$, increases with the fluorination degree of the ligand (the Laplacian of the electron density being an indicator of the covalent or closed shell character of a bond). Fourth, the relation between the potential $(|V|)$ and kinetic energy $(G)$ at the BCP, also indicates that the Au-P bond is intermediate between a covalent and a closed shell interaction. Both parameters $\left(\nabla^{2} \rho\left(\mathbf{r}_{\mathrm{BCP}}\right)\right.$ and $\left.\mid V / / G\right)$ indicate a decrease in the covalent character and a rise of the closed shell nature of the Au$\mathrm{P}$ bond as the degree of fluorination of the ligands is increased. Thus, the lack of change in the Au-P distances could be explained considering that while the covalent character of the bond decreases the coulombic attraction increases maintaining the length of the bond nearly constant.

We observe the same trend concerning the covalent and closed shell features of the Au-P bond in compounds 1a-d and 2a-d with respect to the fluorination degree of the ligands. Our results suggest that this reduction in covalency is related to a decrease in the stability of the examined compounds.

Tong et al. ${ }^{[23]}$ found that there is a good correlation between the ${ }^{31} \mathrm{P}$-NMR chemical shift and the atomic equilibrium electronegativity of the $\mathrm{P}$ atom. This parameter can be estimated as the sum of the group electronegativities of the moieties bonded to phosphorus. The shielding of the $\mathrm{P}$ atom increases with the electronegativity of this atom. This behavior is consistent throughout these phosphines and their complexes. We found a good indicator of $P$ equilibrium electronegativity in the QTAIM charge observed in the gold atom. The change of fluorinated electronegative phenyl groups for less electronegative pheny fragments reduces the equilibrium atomic electronegativity of the $P$ atom. This circumstance influences the electron density distribution of the P-Au bond and this effect can be directly observed on $q_{\mathrm{Au}}$.

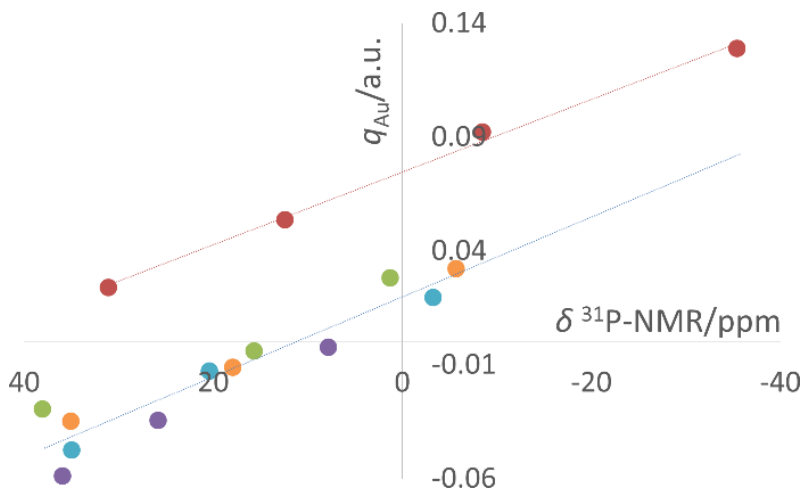

Figure 4. Relation between the gold atom charge and the ${ }^{31} \mathrm{P}-\mathrm{NMR}$ chemical shift $\left(\mathrm{CDCl}_{3}\right)$. Colour code for anionic ligands: red, chloride; green, $-\mathrm{SCF}_{3}$; purple, ${ }^{-} \mathrm{SCH}_{2} \mathrm{CF}_{3}$; orange, ${ }^{-} \mathrm{SC}_{6} \mathrm{~F}_{4}\left(\mathrm{CF}_{3}\right)-4$; blue, ${ }^{-} \mathrm{SC}_{6} \mathrm{~F}_{5}$. 
Figure 4 shows the plot of the Au atom charge as a function of the ${ }^{31} \mathrm{P}$-NMR chemical shift for all the investigated compounds. The different colors indicate the distinct anionic ligands bonded to gold. The distance between the lines evidences the different trans influences of chlorine and fluorothiolate ligands. The difference in the $y$-intercept of the straight lines shown in Figure 4 is produced by the change in the shielding of the phosphorus atom due to the differences of the ligands in trans positions. The atomic equilibrium electronegativity of the phosphorus atom is smaller when the anionic ligand is a fluorothiolate as revealed by the low field chemical shift of the phosphorus atom which is related to a less positive charge of the Au atom. This result can be rationalized in view of the larger electron donor character of sulfur with respect to chlorine. Because S provides more electron density to $\mathrm{Au}$, it decreases more markedly the electronegativity of the metal center. Therefore, the $\mathrm{P}$ equilibrium electronegativity is reduced as well, a condition which unshields the $P$ nuclei. Small variations are observed within the different thiolate derivatives with changes in the fluorinated moiety since the effect over the ${ }^{31} \mathrm{P}$ nucleus diminishes with the distance between $P$ and $R_{F}$ groups.

The Au-P and Au-S distance changes in the crystal structures of compounds $\mathbf{1 a}$ and $\mathbf{1} \mathbf{b}$ (Figure 5) are inconsequential and do not reflect the marked differences observed in the $\delta{ }^{31} \mathrm{P}$ NMR for these systems. We performed theoretical analyses of the phosphine exchange reactions for the compounds of the type $\left[\mathrm{Au}\left(\mathrm{SR}_{\mathrm{F}}\right)\left(\mathrm{PPh}_{\mathrm{F}}\right)\right]$ in a similar way that it was done for the chlorine adducts. We found that the most stable compounds are formed
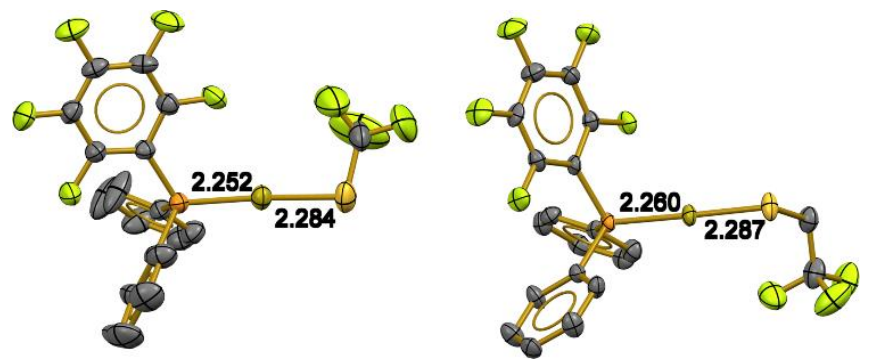

Figure 5. ORTEP diagrams at $40 \%$ probability level of the X-ray structures of compounds 1a and 1b. Colour code: orange, P; golden, Au; yellow, S; green, F; grey, C. hydrogen atoms were omitted for clarity.

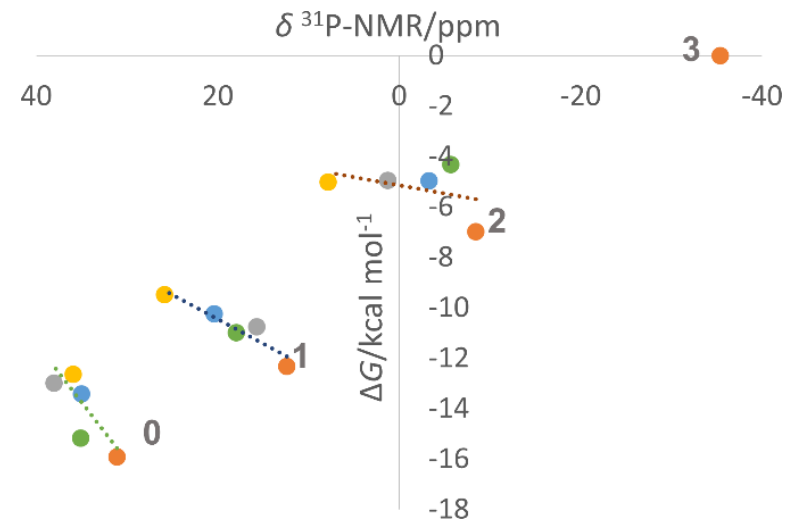

Figure 6. Correlation of $\Delta \mathrm{G}$ for the phosphine substitution reaction and ${ }^{31} \mathrm{P}-\mathrm{NMR}$ chemical shift in $\mathrm{CDCl}_{3}$. The label indicates the phosphine in the data cluster, $\mathrm{P}\left(\mathrm{C}_{6} \mathrm{H}_{5}\right)_{3} \mathbf{0}, \mathrm{P}\left(\mathrm{C}_{6} \mathrm{H}_{5}\right)_{2}\left(\mathrm{C}_{6} \mathrm{~F}_{5}\right)$ 1, $\mathrm{P}\left(\mathrm{C}_{6} \mathrm{H}_{5}\right)\left(\mathrm{C}_{6} \mathrm{~F}_{5}\right)_{2} 2$ and $\mathrm{P}\left(\mathrm{C}_{6} \mathrm{~F}_{5}\right)_{3}$ 3, [AuX(PPh3)]. The colour code for the anionic ligands is as follows: orange, chloride; gray, $\mathrm{SCF}_{3}$; yellow, ${ }^{-} \mathrm{SCH}_{2} \mathrm{CF}_{3}$; green, ${ }^{-} \mathrm{SC}_{6} \mathrm{~F}_{4}\left(\mathrm{CF}_{3}\right)-4$; blue, ${ }^{-} \mathrm{SC}_{6} \mathrm{~F}_{5}$. by the less fluorinated phosphines regardless of the considered thiolate ligand. Additionally, Figure 6 shows the cumulative $\Delta G$ of the phosphine substitution reactions for the different anionic ligands as a function of the ${ }^{31} \mathrm{P}-\mathrm{NMR}$ chemical shift. These plots reveal that the exchange of $\mathrm{Cl}^{-}$for ${ }^{-} \mathrm{SR}_{\mathrm{F}}$ anionic ligands reduces the stability of the compounds into the same phosphine family. By extrapolating the observed trend for the $\mathrm{PPh}_{3}$ derivatives, 1a-d and $\mathbf{2 a - d}$ to the not isolated compounds $\mathbf{3 a - d}$, we could expect that the stability decreases with respect to that of compound $\mathbf{3}$ a condition which explains the problematic isolation of these complexes ${ }^{\ddagger}$. The introduction of the thiolate groups also decreases the covalent character of the Au-P bond as it can be seen in the values of $\nabla^{2} \rho\left(r_{\mathrm{BCP}}\right)$ and $|V| / G$, and hence, the stability of the examined compounds is directly affected by the covalent character of the Au-P bond.

The charge of the Au center in the unstable compounds 3ad is positive. The subsequent reduction of the fluorination degree in the phosphines increases the electronic density over the gold center to the point that $A u$ is slightly negative within triphenylphosphine compounds. The positive charge in the gold atoms of the set $\mathbf{3 x}$ make them good electrophilic centers.

We proceed to discuss now the dissociative or associative nature of the mechanism of substitution of the considered phosphines as shown in Scheme 2. On the one hand, the abovementioned gold positive charge, the low coordinating nature of the solvent ( $\mathrm{CDCl}_{3}$ in the experiment) and the known stability of some three-coordinated gold species ${ }^{[28,29]}$ are factors that support an

Scheme 2. Proposed associative (top) and dissociative (bottom) mechanisms for the phosphine substitution reaction.

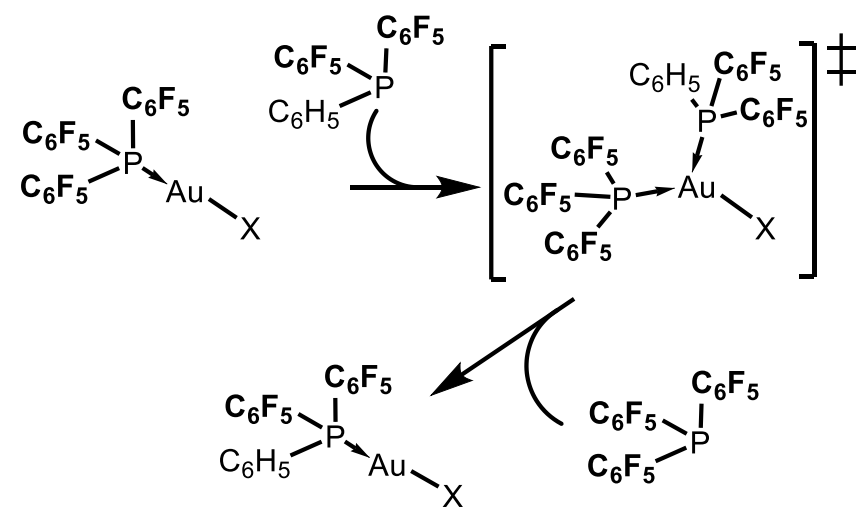

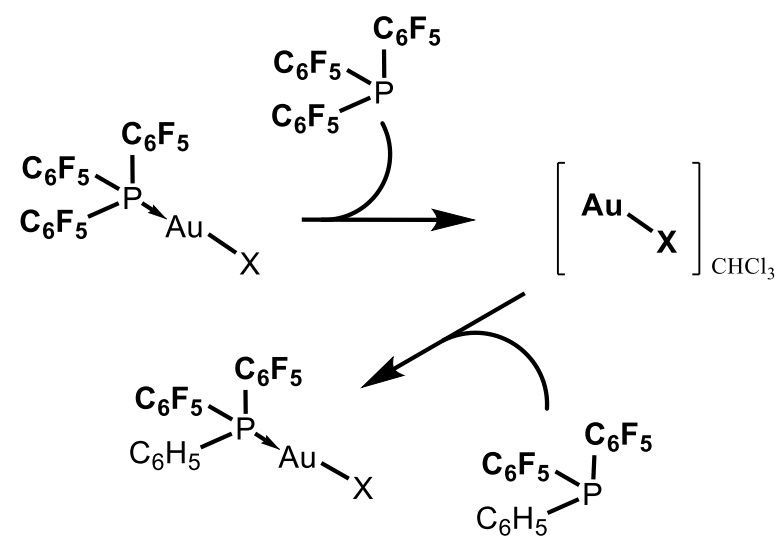


associative process for the reaction of ligand substitution. Additionally, the dissociation energy of the phosphine from compound 3 has a calculated energetic barrier of $45.2 \mathrm{kcal} / \mathrm{mol}$, a condition which suggests that this process is not plausible under the experimental conditions ${ }^{\S}$. These results suggest an associative process in which after the nucleophilic attack of the less fluorinated phosphine, the dissociation of the more fluorinated phosphine (which is less covalently bound to the gold center) occurs, thereby forming the product of the reaction. On the other hand, we did not find NMR evidence of either the threecoordinated species (TCS) related to the associative mechanism or the free phosphine linked to the dissociative mechanism (Spectra available in the ESI). We point out that it is possible that the signals of these species could not necessarily be detectable in the case that only a small fraction of the complexes dissociate or the concentration of the TCS intermediary is too low. A rapid equilibrium of the TCS with free and coordinated phosphine would also impair the detection of the first two-mentioned species. Overall, our analysis suggests an associative mechanism but a dissociative process cannot be conclusively discarded

The catalytic activity of gold adducts is strongly influenced by the electronic environment of the Au centers ${ }^{[1,21,30-34]}$. The results of this investigation indicate that such catalytic activity could be modulated via the fluorination of the ligands. When the shielding of the phosphorus atom rises, the positive charge of the gold atom increases, and the compound becomes more susceptible to suffer nucleophilic attacks in the Au center. These conditions are indicative of an enhanced reactivity of the catalyst, but concomitantly, a decrease in its stability. Conversely, a reduction of the fluorination degree must give more stable compounds resulting in a higher selectivity.

\section{Conclusions}

We investigated the stability and trans influence in a series of gold compounds bearing fluorinated phosphines and thiolates. A rise in the fluorination degree of the ligands in the compounds shields the $P$ nuclei. This change is related to the increase of the phosphorus equilibrium electronegativity. The change of chlorine for a thiolate changes the ${ }^{31} \mathrm{P}-\mathrm{NMR}$ chemical shift to low field due to the trans influence of the ligand along the Au-P bond. This influence is evidenced by the observed trends in the QTAIM charge of the gold atom. The electron density topological analyses of the examined systems show that the fluorination of the phosphines and the inclusion of fluorinated thiolate ligands decrease the covalent character of the Au-P bond. This circumstance is related with the loss of stability of the molecules of interest for this work. Overall, the observed variations in the electronic environment of the gold center could be used to modulate the selectivity and activity of the examined systems as potential catalysts via the valuable explanatory power of the QTAIM methodology.

\section{Experimental Section}

Instrumentation: melting points were obtained using a Fisher-Johns apparatus. Infrared spectra were recorded on a Perkin-Elmer FTIR/FIR Spectrum 400 spectrometer in the range of 4000 to $400 \mathrm{~cm}^{-1}$ using Attenuated Total Reflectance. Elemental analyses were performed using a Thermo Scientific Flash 2000 Analyser at $950{ }^{\circ} \mathrm{C} .{ }^{1} \mathrm{H}$ and ${ }^{13} \mathrm{C}$ NMR spectra were registered on a 9.4 T Varian VNMRS spectrometer while ${ }^{19} \mathrm{~F}$ and ${ }^{31} \mathrm{P}\left\{{ }^{1} \mathrm{H}\right\}$ NMR were obtained on a 7.0 T Oxford Spectrometer. Chemical shifts are in ppm relative to internal TMS $\delta=0 \mathrm{ppm}\left({ }^{1} \mathrm{H}\right)$ and to external references of $\mathrm{CFCl}_{3}$ (for ${ }^{19} \mathrm{~F}$ ) and $\mathrm{H}_{3} \mathrm{PO}_{4}$ (for ${ }^{31} \mathrm{P}$ ) at $0 \mathrm{ppm}$. $J$ values are given in $\mathrm{Hz}$, all spectra were collected from fresh solutions under sealed $\mathrm{N}_{2}$ atmosphere. Positive-ion fast atom bombardment mass spectrometry spectra were recorded on an MStation JMS-700 mass spectrometer operated at an acceleration voltage of $10 \mathrm{kV}$. Samples were desorbed from a 3-nitrobenzyl alcohol matrix by $3 \mathrm{keV}$ xenon atoms employing the matrix ions as the reference material.

All thiols and phosphines were purchased from Sigma-Aldrich Co. and used without further purification. Chlorotetrahydrothiophenegold(I)

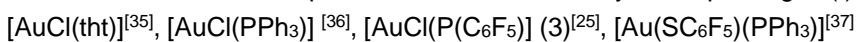
and $\mathrm{AgSCF}_{3}{ }^{[38]}$ were prepared following the procedures reported in the literature. Lead thiolates ${ }^{[39]}$ were obtained by the reaction of stoichiometrical quantities of lead acetate dissolved in an excess of deionized water with the corresponding thiol dissolved in a small amount of methanol. $\mathrm{AgSCF}_{3}$ is used as source of $\mathrm{SCF}_{3}$ because the equivalent lead thiolate is instable.

Synthesis. Because compounds 1 and $\mathbf{2}$ were synthesized in similar ways, only the synthesis of $\mathbf{1}$ is explained in detail.

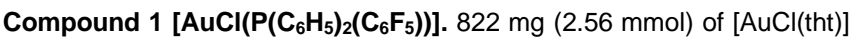
(tht = tetrahydrotiophene) were stirred in $50 \mathrm{~mL}$ of dichloromethane at room temperature together with $903 \mathrm{mg}(2.56 \mathrm{mmol})$ of $\mathrm{P}\left(\mathrm{C}_{6} \mathrm{H}_{5}\right)_{2}\left(\mathrm{C}_{6} \mathrm{~F}_{5}\right)$ for 3 hours. The formed colorless solution was reduced in volume to about 5 $\mathrm{mL}$ and an excess of hexane was added forming a white powder. Yield $91 \%$ (1.31 g, $2.33 \mathrm{mmol}$ ); $\mathrm{mp} 169-171^{\circ} \mathrm{C}$ (from hexane/ $\mathrm{CHCl}_{3}$ ), elemental analysis (found: $\mathrm{C}, 37.2 \% ; \mathrm{H}, 2.1 \%$. Calc. for $\mathrm{C}_{18} \mathrm{H}_{10} \mathrm{AuClF}_{5} \mathrm{P}: \mathrm{C}, 36.98 \%$; $\mathrm{H}, 1.7 \%$ ), FTIR: $\mathrm{V}_{\max } / \mathrm{cm}^{-1} 534.70$ and $688.12(\mathrm{P}-\mathrm{C}), 1025.48$ (P-Au), $745.05,1436.54$ and $1644.23(\mathrm{C}=\mathrm{C}), 979.39,1093.36,1478.42$ and $1516.93(\mathrm{C}-\mathrm{F}), 3055.16$ and $3038.06\left(\mathrm{C}-\mathrm{H}_{\mathrm{ar}}\right)$. Mass spectrum M/Z: $584\left(\mathrm{M}^{+}\right.$, $5 \%), 549\left(\left[\mathrm{Au}\left(\mathrm{PPh}_{\mathrm{F}}\right)\right]^{+}, 100\right) \cdot \delta^{19} \mathrm{~F}\left(282 \mathrm{MHz} ; \mathrm{CDCl}_{3} ; \mathrm{CFCl}_{3}\right):-126.9(2 \mathrm{~F}, \mathrm{~m}$, oF), -148.3 (1F, m, pF), -160.4 (2F, m, mF); $\delta^{31} \mathrm{P}\left\{{ }^{1} \mathrm{H}\right\}$ (122 MHz, $\mathrm{CDCl}_{3}$, $\left.\mathrm{H}_{3} \mathrm{PO}_{4}\right): 18.6\left(1 \mathrm{P}, \mathrm{t},{ }^{3} \mathrm{JFP}_{\mathrm{FP}}=15.70 \mathrm{~Hz}, \mathrm{PR}_{3}\right)$. Multi-day slow evaporation of solutions of the compound in dichloromethane gave $\mathrm{X}$-ray suitable crystals.

Compound 2 [AuCl( $\left.\left(\mathbf{P}_{(}\left(\mathbf{C}_{6} \mathbf{H}_{5}\right)\left(\mathbf{C}_{6} \mathbf{F}_{5}\right)_{2}\right)\right] .82 \%(1.22 \mathrm{~g}, 1.82 \mathrm{mmol})$, mp 171$173{ }^{\circ} \mathrm{C}$ (from hexane/ $\mathrm{CH}_{2} \mathrm{Cl}_{2}$ ), elemental analysis (found: $\mathrm{C}, 30.9 \% ; \mathrm{H}$, 1.1\%. Calc. for $\mathrm{C}_{18} \mathrm{H}_{5} \mathrm{AuClF}_{10} \mathrm{P}$ : C, $\left.30.6 \% ; \mathrm{H}, 0.7 \%\right)$, FTIR: $\mathrm{V}_{\max } / \mathrm{cm}^{-1}$ 523.51 and 688.84 (P-C), 1025.52 (P-Au), 745.26, 1438.24 and 1644.96 $(C=C), 977.73,1094.20,1474.94$ and $1520.19(\mathrm{C}-\mathrm{F}), 3049.79$ and 2935.53 (C-Har). Mass spectrum M/z: $792(15 \%), 639\left(\left[\mathrm{Au}\left(\mathrm{PPh}_{\mathrm{F}}\right)\right]^{+}, 100\right) . \delta^{19} \mathrm{~F}(282$ $\left.\mathrm{MHz} ; \mathrm{CDCl}_{3} ; \mathrm{CFCl}_{3}\right):-127.4(2 \mathrm{~F}, \mathrm{~m}, \mathrm{oF}),-143.6(1 \mathrm{~F}, \mathrm{~m}, \mathrm{pF}),-157.3(2 \mathrm{~F}, \mathrm{~m}$, $\mathrm{mF}) ; \delta^{31} \mathrm{P}\left\{{ }^{1} \mathrm{H}\right\}\left(122 \mathrm{MHz}, \mathrm{CDCl}_{3}, \mathrm{H}_{3} \mathrm{PO}_{4}\right):-5.9\left(1 \mathrm{P}, \mathrm{m}, \mathrm{PR}_{3}\right)$.

[Au( $\left.\left.\mathbf{S C F}_{3}\right)\left(\mathrm{PPh}_{3}\right)\right] .150 \mathrm{mg}(0.256 \mathrm{mmol})$ of $\left[\mathrm{AuCl}\left(\mathrm{PPh}_{3}\right)\right]$ in $20 \mathrm{~mL}$ of dichloromethane and $53.6 \mathrm{mg}(0.256 \mathrm{mmol})$ of $\mathrm{AgSCF}_{3}$ were mixed under continuous stirring in a $50 \mathrm{~mL}$ Schlenk flask. After $3 \mathrm{~h}$, the formed white suspension was filtered off to obtain solid, white $\mathrm{AgCl}$ and a clear solution whose volume was diminished until about $2 \mathrm{~mL}$ by reduced pressure evaporation. An excess of hexane was added to the last-mentioned solution and a white powder was formed. Yield $80 \%$ (114.7 mg, 0.205 
mmol), $\mathrm{mp} 109-110{ }^{\circ} \mathrm{C}$. Elemental analysis (found: $\mathrm{C}, 40.9 \% ; \mathrm{H}, 2.9 \%$. Calc. for $\mathrm{C}_{19} \mathrm{H}_{15} \mathrm{AuF}_{3} \mathrm{PS}$ : C, $40.7 \%$; H, 2.7\%), FTIR: $\mathrm{V}_{\max } / \mathrm{cm}^{-1} 689.82$ and 997.53 (P-C), 1026.34 (P-Au), 1435.35 and $1479.88(\mathrm{C}=\mathrm{C}), 1078.11 \mathrm{br}(\mathrm{C}-$ F), 3054.83 and $3073.18\left(\mathrm{C}-\mathrm{H}_{\mathrm{ar}}\right)$. Mass spectrum M/z: $459\left(\left[\mathrm{Au}\left(\mathrm{PPh}_{\mathrm{F}}\right)\right]^{+}\right.$, $100 \%) . \delta^{1} \mathrm{H}\left(400 \mathrm{MHz}\right.$; $\mathrm{CDCl}_{3}$; TMS) $7.7-7.6\left(15 \mathrm{H}, \mathrm{m}, \mathrm{PPh}_{3}\right) ; \delta^{19} \mathrm{~F}(282$ $\left.\mathrm{MHz} ; \mathrm{CDCl}_{3} ; \mathrm{CFCl}_{3}\right):-19.0\left(3 \mathrm{~F}, \mathrm{~s}, \mathrm{CF}_{3}\right) ; \delta^{31} \mathrm{P}\left\{{ }^{1} \mathrm{H}\right\}\left(122 \mathrm{MHz}, \mathrm{CDCl}_{3}\right.$, $\left.\mathrm{H}_{3} \mathrm{PO}_{4}\right): 38.1\left(1 \mathrm{P}, \mathrm{s}, \mathrm{PR}_{3}\right)$

Compound 1a $\left[\mathrm{Au}\left(\mathrm{SCF}_{3}\right)\left(\mathrm{P}\left(\mathrm{C}_{6} \mathrm{H}_{5}\right)_{2}\left(\mathrm{C}_{6} \mathrm{~F}_{5}\right)\right)\right] .117 \mathrm{mg}(0.2 \mathrm{mmol})$ of 1 in 20 $\mathrm{mL}$ of dichloromethane and $42 \mathrm{mg}(0.2 \mathrm{mmol})$ of $\mathrm{AgSCF}_{3}$ were mixed under continuous stirring in a $50 \mathrm{~mL}$ round Schlenk flask under $\mathrm{N}_{2}$ atmosphere. After $3 \mathrm{~h}$, the formed white suspension was filtered off to obtain solid, white $\mathrm{AgCl}$ and a clear solution whose volume was diminished until about $2 \mathrm{~mL}$ by reduced pressure evaporation. An excess of hexane was added to the last-mentioned solution and a white powder was formed. Yield $89 \%$, mp $169-171{ }^{\circ} \mathrm{C}$ (from hexane/ $\mathrm{CHCl}_{3}$ ), elemental analysis (found: $\mathrm{C}, 37.2 \%$; $\mathrm{H}, 2.0 \%$. Calc. for $\mathrm{C}_{18} \mathrm{H}_{10} \mathrm{AuClF}_{5} \mathrm{P}: \mathrm{C}, 37.0 \%$; $\mathrm{H}, 1.7 \%$ ), FTIR: $V_{\max } / \mathrm{cm}^{-1} 534.70$ and $688.12(\mathrm{P}-\mathrm{C}), 1025.48(\mathrm{P}-\mathrm{Au}), 745.05$, 1436.54 and $1644.23(\mathrm{C}=\mathrm{C}), 979.39,1093.36,1478.42$ and 1516.93 (CF), 3055.16 and $3038.06\left(\mathrm{C}-\mathrm{H}_{\mathrm{ar}}\right)$. Mass spectrum M/z: $549\left(\left[\mathrm{Au}\left(\mathrm{PPh}_{\mathrm{F}}\right)\right]^{+}\right.$, $17 \%) . \delta^{19} \mathrm{~F}\left(282 \mathrm{MHz} ; \mathrm{CDCl}_{3} ; \mathrm{CFCl}_{3}\right):-126.9$ (2F, m, oF), -148.3 (1F, m, pF), -160.4 (2F, m, mF); $\delta^{31} \mathrm{P}\left\{{ }^{1} \mathrm{H}\right\}\left(122 \mathrm{MHz}, \mathrm{CDCl}_{3}, \mathrm{H}_{3} \mathrm{PO}_{4}\right): 18.6(1 \mathrm{P}, \mathrm{t}$, $\left.{ }^{3} J_{P-F}=15.7 \mathrm{~Hz}, \mathrm{PR}_{3}\right)$.

Compound 2a $\left[\mathrm{Au}\left(\mathrm{SCF}_{3}\right)\left(\mathbf{P}\left(\mathrm{C}_{6} \mathrm{H}_{5}\right)\left(\mathrm{C}_{6} \mathrm{~F}_{5}\right)_{2}\right)\right]$. The protocol for the synthesis of this compound is equivalent to that of compound 1a with the difference that it starts with the mixing of $135 \mathrm{mg}$ of 2 with $42 \mathrm{mg}(0.2 \mathrm{mmol})$ of $\mathrm{AgSCF}_{3}$. Yield $67 \%$ decomposes at $124^{\circ} \mathrm{C}$, elemental analysis (found: $\mathrm{C}$, $31.1 \%$; $\mathrm{H}, 1.0 \%$. Calc. for $\mathrm{C}_{19} \mathrm{H}_{5} \mathrm{AuF}_{10} \mathrm{PS}$ : C, $30.8 \%$; $\left.\mathrm{H}, 0.7 \%\right)$, FTIR: $V_{\max } / \mathrm{cm}^{-1} 520.19$ and $688.05(\mathrm{P}-\mathrm{C}), 741.30,1439.15$ and $1644.19(\mathrm{C}=\mathrm{C})$, 979.83, 1081.75, 1475.45 and 1522.98 (C-F), 3053.44 and 2965.42 (C$\mathrm{H}_{\text {ar). }}$. Mass spectrum $M / z: 741\left(\{\mathrm{M}+1\}^{+}, 10 \%\right), 639(100), 442(31), 562(4)$, 936(8), 275(47). $\delta^{19} \mathrm{~F}\left(282 \mathrm{MHz} ; \mathrm{CDCl}_{3}\right.$; $\left.\mathrm{CFCl}_{3}\right):-20.3\left(3 \mathrm{~F}, \mathrm{~s}, \mathrm{SCF}_{3}\right),-127.4$ (2F, m, oF), -143.5 (1F, m, pF), -157.2 (2F, m, mF); $\delta^{31} \mathrm{P}\left\{{ }^{1} \mathrm{H}\right\}(122 \mathrm{MHz}$, $\left.\mathrm{CDCl}_{3}, \mathrm{H}_{3} \mathrm{PO}_{4}\right): 1.3\left(1 \mathrm{P}, \mathrm{s}, \mathrm{PR}_{3}\right)$.

Compounds [Au( $\left.\left.\mathrm{SR}_{\mathrm{F}}\right)\left(\mathrm{PPh}_{3}\right)\right]$ (with $\mathrm{R}_{\mathrm{F}}=\mathrm{CH}_{2} \mathrm{CF}_{3}$ and $\mathrm{C}_{6} \mathrm{~F}_{4}\left(\mathrm{CF}_{3}\right)-4$, $\mathbf{1 b}-\mathbf{d}$ and $\mathbf{2 b}$-d were synthesized in an analogous way to $\left[\mathrm{Au}\left(\mathrm{SCF}_{3}\right)\left(\mathrm{PPh}_{3}\right)\right]$, 1a and $2 \mathrm{a}$ respectively but using the corresponding lead thiolates.

[Au( $\left.\left.\mathrm{SCH}_{2} \mathrm{CF}_{3}\right)\left(\mathrm{PPh}_{3}\right)\right]$. White powder (146 mg, 88\%), elemental analysis (found: $\mathrm{C}, 41.6 \%$; $\mathrm{H}, 3.1 \%$. Calc. for $\mathrm{C}_{20} \mathrm{H}_{17} \mathrm{AuF}_{3} \mathrm{PS}$ : C, $41.8 \%$; $\mathrm{H}, 3.0 \%$ ). Mass spectrum M/z: 459 ([Au(PPhF) $\left.]^{+}, 45 \%\right) . \delta^{1} \mathrm{H}\left(400 \mathrm{MHz} ; \mathrm{CDCl}_{3} ; \mathrm{TMS}\right)$ 7.6 - $7.4\left(15 \mathrm{H}, \mathrm{m}, \mathrm{PPh}_{3}\right), 3.5\left(2 \mathrm{H}, \mathrm{q},{ }^{3} \mathrm{JH}_{\mathrm{H}-\mathrm{F}}=9.9 \mathrm{~Hz}, \mathrm{CH}_{2}\right), \delta^{19} \mathrm{~F}(282 \mathrm{MHz}$; $\left.\mathrm{CDCl}_{3} ; \mathrm{CFCl}_{3}\right):-70.8\left(3 \mathrm{~F}, \mathrm{t},{ }^{3} \mathrm{~J}_{F-H}=9.9 \mathrm{~Hz}, \mathrm{CF}_{3}\right) ; \delta^{31} \mathrm{P}\left\{{ }^{1} \mathrm{H}\right\}\left(122 \mathrm{MHz}, \mathrm{CDCl}_{3}\right.$, $\left.\mathrm{H}_{3} \mathrm{PO}_{4}\right): 35.9\left(1 \mathrm{P}, \mathrm{s}, \mathrm{PPh}_{3}\right)$.

[Au( $\left.\left(\mathbf{S C}_{6} \mathbf{F}_{4}\left(\mathbf{C F}_{3}\right)-4\right)\left(\mathbf{P P h}_{3}\right)\right]$. White powder (120 mg, 96\%), elemental analysis (found: $\mathrm{C}, 42.3 \% ; \mathrm{H}, 2.1 \%$. Calc. for $\mathrm{C}_{25} \mathrm{H}_{15} \mathrm{AuF}_{7} \mathrm{PS}$ : C, $42.4 \%$; $\mathrm{H}$, $2.1 \%)$. Mass spectrum M/z: 459 ([Au(PPhF) $\left.]^{+}, 28 \%\right) . \delta^{1} \mathrm{H}(400 \mathrm{MHz}$; $\mathrm{CDCl}_{3}$; TMS) $7.6-7.5$ (15H, m, PPh $) ; \delta^{19} \mathrm{~F}\left(282 \mathrm{MHz} ; \mathrm{CDCl}_{3} ; \mathrm{CFCl}_{3}\right)$ : 58.5--58.2 (3F, m, CF $),-134.2(2 \mathrm{~F}, \mathrm{~m}, \mathrm{oF}),-146.8(2 \mathrm{~F}, \mathrm{~m}, \mathrm{mF}) ; \delta^{31} \mathrm{P}\{1 \mathrm{H}\}$ $\left(122 \mathrm{MHz}, \mathrm{CDCl}_{3}, \mathrm{H}_{3} \mathrm{PO}_{4}\right): 35.1\left(1 \mathrm{P}, \mathrm{s}, \mathrm{PPh}_{3}\right)$

Compound 1b $\left[\mathrm{Au}\left(\mathrm{SCH}_{2} \mathrm{CF}_{3}\right)\left(\mathbf{P}\left(\mathbf{C}_{6} \mathbf{H}_{5}\right)_{2}\left(\mathbf{C}_{6} \mathbf{F}_{5}\right)\right)\right]$. Yellowish powder (155 $\mathrm{mg}, 87 \%$ ) decomposes at $126{ }^{\circ} \mathrm{C}$, elemental analysis (found: $\mathrm{C}, 35.8 \% ; \mathrm{H}$,
1.6\%. Calc. for $\left.\mathrm{C}_{20} \mathrm{H}_{12} \mathrm{AuF}_{8} \mathrm{PS}: \mathrm{C}, 36.16 \% ; \mathrm{H}, 1.82 \%\right)$, FTIR: $\mathrm{V}_{\max } / \mathrm{cm}^{-1}$ 526.32 and 692.98 (P-C), 1027.76 (P-Au), 748.91, 1438.37 and 1643.35 $(C=C), 979.70,1090.28,1477.93$ and $1516.84(C-F), 3077.93$ and 2953.43 (C-Har), $2923.87(\mathrm{C}-\mathrm{H})$. Mass spectrum M/z: $665\left(\{\mathrm{M}+1\}^{+}, 10 \%\right), 549(100)$ 352 (5), 275 (9), 183 (18). $\delta^{19} \mathrm{~F}\left(282 \mathrm{MHz} ; \mathrm{CDCl}_{3} ; \mathrm{CF}_{3} \mathrm{CO}_{2} \mathrm{H}\right):-68.2(3 \mathrm{~F}, \mathrm{t}$, $\left.{ }^{3} \mathrm{JHF}_{\mathrm{HF}}=9.83 \mathrm{~Hz}, \mathrm{CF}_{3}\right),-125.9(2 \mathrm{~F}, \mathrm{~m}, \mathrm{oF}),-145.2(1 \mathrm{~F}, \mathrm{~m}, \mathrm{pF}),-158.0(2 \mathrm{~F}, \mathrm{~m}$, $\mathrm{mF}) ; \delta^{31} \mathrm{P}\left\{{ }^{1} \mathrm{H}\right\}\left(122 \mathrm{MHz}, \mathrm{CDCl}_{3}, \mathrm{H}_{3} \mathrm{PO}_{4}\right): 22.0$ (1P, s, $\left.\mathrm{PR}_{3}\right)$.

Compound 1c $\left[\mathbf{A u}\left(\mathbf{S C}_{6} \mathbf{F}_{5}\right)\left(\mathbf{P}\left(\mathbf{C}_{6} \mathbf{H}_{5}\right)_{2}\left(\mathbf{C}_{6} \mathbf{F}_{5}\right)\right)\right]$. Yellowish powder (172 mg, $91 \%$ ) decomposes at $145{ }^{\circ} \mathrm{C}$, elemental analysis (found: $\mathrm{C}, 38.8 \% ; \mathrm{H}$, 1.2\%. Calc. for $\mathrm{C}_{24} \mathrm{H}_{10} \mathrm{AuF}_{10} \mathrm{PS}$ : C, 38.52\%; H, 1.35\%), FTIR: $\mathrm{v}_{\max } / \mathrm{cm}^{-1}$ 531.69 and 689.03 (P-C), 1025.43 (P-Au), 740.27, 1437.22 and 1644.41 $(\mathrm{C}=\mathrm{C}), 979.81,1078.21,1478.42$ and 1523.68 (C-F), 3077.93 and 2958.61 (C-Har). Mass spectrum M/z: $748\left(\mathrm{M}^{+}, 20 \%\right) 549$ (100), 472 (6), 275 (25), 199 (28). $\delta^{19} \mathrm{~F}\left(282 \mathrm{MHz} ; \mathrm{CDCl}_{3} ; \mathrm{CF}_{3} \mathrm{CO}_{2} \mathrm{H}\right)$ : -132.91 (2F, m, oF $\left(\mathrm{SC}_{6} \mathrm{~F}_{5}\right)$ ), $-162.6\left(1 \mathrm{~F}, \mathrm{~m}, \mathrm{pF}\left(\mathrm{SC}_{6} \mathrm{~F}_{5}\right)\right)$ and $-164.6\left(2 \mathrm{~F}, \mathrm{~m}, \mathrm{mF}\left(\mathrm{SC}_{6} \mathrm{~F}_{5}\right)\right),-126.2(2 \mathrm{~F}, \mathrm{~m}$ oF $\left.\left(\mathrm{C}_{6} \mathrm{~F}_{5}\right)\right)$, -145.3 (1F, m, pF( $\left.\left.\mathrm{C}_{6} \mathrm{~F}_{5}\right)\right),-158.3\left(2 \mathrm{~F}, \mathrm{~m}, \mathrm{mF}\left(\mathrm{C}_{6} \mathrm{~F}_{5}\right)\right) ; \delta^{31} \mathrm{P}\left\{{ }^{1} \mathrm{H}\right\}$ (122 MHz, $\left.\mathrm{CDCl}_{3}, \mathrm{H}_{3} \mathrm{PO}_{4}\right): 20.4\left(1 \mathrm{P}, \mathrm{s}, \mathrm{PR}_{3}\right)$.

Compound 1d $\left[\mathrm{Au}\left(\mathrm{SC}_{6} \mathrm{~F}_{4}\left(\mathrm{CF}_{3}\right)-4\right)\left(\mathrm{P}_{(}\left(\mathrm{C}_{6} \mathrm{H}_{5}\right)_{2}\left(\mathrm{C}_{6} \mathrm{~F}_{5}\right)\right)\right]$. White powder (172mg, 84\%) decomposes at $120{ }^{\circ} \mathrm{C}$, elemental analysis (found: $\mathrm{C}$, $36.85 \% ; \mathrm{H}, 1.19 \%$. Calc. for $\mathrm{C}_{24} \mathrm{H}_{10} \mathrm{AuF}_{10} \mathrm{PS}$ : C, $37.61 \%$; $\mathrm{H}, 1.26 \%$ ), FTIR: $\mathrm{V}_{\max } / \mathrm{cm}^{-1} 518.01$ and $688.22(\mathrm{P}-\mathrm{C}), 1025.70(\mathrm{P}-\mathrm{Au}), 744.93,1437.52$ and 1644.48 (C=C), 979.57, 1093.84, 1478.22 and $1518.34(\mathrm{C}-\mathrm{F}), 3055.81$ and $1587.66\left(\mathrm{C}-\mathrm{H}_{\mathrm{ar}}\right)$. Mass spectrum M/z: $798\left(\mathrm{M}^{+}, 3 \%\right), 549(100), 352(19)$, $183(73) . \delta^{19} \mathrm{~F}\left(282 \mathrm{MHz} ; \mathrm{CDCl}_{3} ; \mathrm{CF}_{3} \mathrm{CO}_{2} \mathrm{H}\right):-58.5\left(3 \mathrm{~F}, \mathrm{~s}, \mathrm{CF}_{3}\right),-134.4(2 \mathrm{~F}$, $\mathrm{m}$, oF $\left.\left(\mathrm{SC}_{6} \mathrm{~F}_{4} \mathrm{CF}_{3}\right)\right),-146.8\left(2 \mathrm{~F}, \mathrm{~m}, \mathrm{mF}\left(\mathrm{SC}_{6} \mathrm{~F}_{4} \mathrm{CF}_{3}\right)\right),-128.8(2 \mathrm{~F}, \mathrm{~m}$, of $\left.\left(\mathrm{C}_{6} \mathrm{~F}_{5}\right)\right),-147.5\left(1 \mathrm{~F}, \mathrm{~m}, \mathrm{pF}\left(\mathrm{C}_{6} \mathrm{~F}_{5}\right)\right),-160.7\left(2 \mathrm{~F}, \mathrm{~m}, \mathrm{mF}\left(\mathrm{C}_{6} \mathrm{~F}_{5}\right)\right) ; \delta^{31} \mathrm{P}\left\{{ }^{1} \mathrm{H}\right\}$ (122 MHz, $\left.\mathrm{CDCl}_{3}, \mathrm{H}_{3} \mathrm{PO}_{4}\right): 18.0$ (1P, s, $\mathrm{PR}_{3}$ ).

Compound 2b $\left[\mathrm{Au}\left(\mathrm{SCH}_{2} \mathrm{CF}_{3}\right)\left(\mathbf{P}\left(\mathrm{C}_{6} \mathrm{H}_{5}\right)\left(\mathrm{C}_{6} \mathbf{F}_{5}\right)_{2}\right)\right]$. Yellowish oil (103 mg, $61 \%)$ air sensitive. Mass spectrum $M / z$ : $950\left(\{\mathrm{M}+\mathrm{Au}\}^{+}, 5 \%\right), 639$ (100), 442 (16), 562 (3), 459 (16). $\delta^{19} \mathrm{~F}\left(282 \mathrm{MHz} ; \mathrm{CDCl}_{3} ; \mathrm{CF}_{3} \mathrm{CO}_{2} \mathrm{H}\right):-68.4$ (3F, t, JHF $\left.=9.7 \mathrm{MHz}, \mathrm{SCF}_{3}\right),-128.5\left(4 \mathrm{~F}, \mathrm{~m}, \mathrm{oF}\left(\mathrm{C}_{6} \mathrm{~F}_{5}\right)\right),-148.8\left(2 \mathrm{~F}, \mathrm{~m}, \mathrm{pF}\left(\mathrm{C}_{6} \mathrm{~F}_{5}\right)\right)$, $159.7\left(4 \mathrm{~F}, \mathrm{~m}, \mathrm{mF}\left(\mathrm{C}_{6} \mathrm{~F}_{5}\right)\right) ; \delta^{31} \mathrm{P}\left\{{ }^{1} \mathrm{H}\right\}\left(122 \mathrm{MHz}, \mathrm{CDCl}_{3}, \mathrm{H}_{3} \mathrm{PO}_{4}\right): 7.8(1 \mathrm{P}, \mathrm{s}$, $\left.\mathrm{PR}_{3}\right)$.

Compound 2c $\left[\mathbf{A u}\left(\mathbf{S C}_{6} \mathbf{F}_{5}\right)\left(\mathbf{P}\left(\mathbf{C}_{6} \mathbf{H}_{5}\right)\left(\mathbf{C}_{6} \mathbf{F}_{5}\right)_{2}\right)\right]$. Colorless oil (99 mg, $\left.66 \%\right)$ air sensitive. Mass spectrum $M / z: 1035\left(\{\mathrm{M}+\mathrm{Au}\}^{+}, 7 \%\right), 639(100) . \delta^{19} \mathrm{~F}$ (282 MHz; $\left.\mathrm{CDCl}_{3} ; \mathrm{CF}_{3} \mathrm{CO}_{2} \mathrm{H}\right)$ : -132.49 (2F, m, oF $\left.\left(\mathrm{SC}_{6} \mathrm{~F}_{5}\right)\right),-161.7(1 \mathrm{~F}, \mathrm{~m}$, $\left.\mathrm{pF}\left(\mathrm{SC}_{6} \mathrm{~F}_{5}\right)\right),-163.9\left(2 \mathrm{~F}, \mathrm{~m}, \mathrm{mF}\left(\mathrm{SC}_{6} \mathrm{~F}_{5}\right)\right),-127.1\left(4 \mathrm{~F}, \mathrm{~m}, \mathrm{oF}\left(\mathrm{C}_{6} \mathrm{~F}_{5}\right)\right),-143.5$ $\left(2 \mathrm{~F}, \mathrm{~m}, \mathrm{pF}\left(\mathrm{C}_{6} \mathrm{~F}_{5}\right)\right),-157.1\left(4 \mathrm{~F}, \mathrm{~m}, \mathrm{mF}\left(\mathrm{C}_{6} \mathrm{~F}_{5}\right)\right) ; \delta^{31} \mathrm{P}\left\{{ }^{1} \mathrm{H}\right\}\left(122 \mathrm{MHz}, \mathrm{CDCl}_{3}\right.$, $\left.\mathrm{H}_{3} \mathrm{PO}_{4}\right):-3.3\left(1 \mathrm{P}, \mathrm{s}, \mathrm{PR}_{3}\right)$

Compound 2d [ $\left.\mathbf{A u}\left(\mathrm{SC}_{6} \mathrm{~F}_{4}\left(\mathrm{CF}_{3}\right)-4\right)\left(\mathbf{P}\left(\mathrm{C}_{6} \mathrm{H}_{5}\right)\left(\mathrm{C}_{6} \mathrm{~F}_{5}\right)_{2}\right)\right]$. Yellowish oil $(91 \mathrm{mg}$, 70\%), air sensitive. Mass spectrum M/z: 1085 ( $\left.\{\mathrm{M}+\mathrm{Au}\}^{+}, 5 \%\right), 639$ (100). $\delta^{19} \mathrm{~F}\left(282 \mathrm{MHz} ; \mathrm{CDCl}_{3} ; \mathrm{CF}_{3} \mathrm{CO}_{2} \mathrm{H}\right):-58.6\left(3 \mathrm{~F}, \mathrm{~s}, \mathrm{CF}_{3}\right),-134.5(2 \mathrm{~F}, \mathrm{~m}$, oF $\left.\left(\mathrm{SC}_{6} \mathrm{~F}_{4} \mathrm{CF}_{3}\right)\right),-146.5\left(2 \mathrm{~F}, \mathrm{~m}, \mathrm{mF}\left(\mathrm{SC}_{6} \mathrm{~F}_{4} \mathrm{CF}_{3}\right)\right),-130.0\left(4 \mathrm{~F}, \mathrm{~m}\right.$, oF $\left.\left(\mathrm{C}_{6} \mathrm{~F}_{5}\right)\right)$ -146.5 (2F, m, pF( $\left.\left.\mathrm{C}_{6} \mathrm{~F}_{5}\right)\right),-160.0\left(4 \mathrm{~F}, \mathrm{~m}, \mathrm{mF}\left(\mathrm{C}_{6} \mathrm{~F}_{5}\right)\right) ; \delta^{31} \mathrm{P}\left\{{ }^{1} \mathrm{H}\right\}(122 \mathrm{MHz}$ $\left.\mathrm{CDCl}_{3}, \mathrm{H}_{3} \mathrm{PO}_{4}\right):-5.7\left(1 \mathrm{P}, \mathrm{s}, \mathrm{PR}_{3}\right)$.

Computational details. Geometry optimizations were carried out using Density Functional Theory along with the Zeroth Order Regular Approximation Hamiltonian. ${ }^{[40,41]}$ We utilized the combination of the BP86 exchange-correlation functional ${ }^{[42,43]}$, the def2-TZVP-ZORA basis set ${ }^{[44]}$ 
and the Grimme's dispersion correction ${ }^{[45,46]}$. In order to speed up the computations, we consider the RI approximation together with the SARC auxiliary basis set ${ }^{[47-49]}$. For the solution phase estimations we used the conductor-like polarizable continuum model[50] where the cavities were built using the GEPOL algorithm ${ }^{[51-53]}$ (Selected radii (bohr):Au 2.8029, S 3.0818, P 2.9798, F 2.2503, C 2.7795, H 1.4566). We performed all the electronic structure calculations in the ORCA program. ${ }^{[54]}$ This methodology has been successfully employed in the description of metalmetal as well as metal-ligand bonding by others ${ }^{[55-57]}$ and in our own research[58,59]. The Quantum Theory of Atoms in Molecules (QTAIM) methodology was used to investigate the chemical bonding scenario in the examined systems. QTAIM is a wave function analysis approach based on the topology of the charge distribution $\boldsymbol{\rho}(\mathrm{r})$ and results in an exhaustive partition of space into disjoint regions that can be identified with the atoms of chemistry. ${ }^{[60,61]}$ The AIMAll package was used to perform the QTAIM analyses $^{[62]}$.

\section{Acknowledgements}

We acknowledge the technical support of USAll at the School of Chemistry, UNAM. We are also thankful to DGAPA-UNAM, CONACYT-Mexico and the Spanish Government for funding through the projects IN210818, CB-2012/177498 and CTQ-201565790-P respectively, along with $\mathrm{PhD}$ scholarships 270993 (G.M.A.) and 381483 (J.M.G.V). We also express our gratitude to DGTIC/UNAM for supercomputer resources (project LANCADUNAM-DGTIC-250) together with Rosa Isela del Villar for the NMR facilities and Luis Turcio-García for experimental assistance. We want to acknowledge the comments of the referees of the paper concerning the associative and dissociative nature of the phosphine substitutions discussed herein. The issues raised by these anonymous colleagues were very useful to improve our discussion in this regard.

Keywords: gold, phosphine, trans influence, fluorine, thiolate, 31P-NMR

\section{References and notes}

¥ We studied the route of decomposition of compound $\mathbf{3 c}$. When we tried to synthesize it, a grey insoluble powder was isolated, IR and EA indicate that this product is the polymeric gold $(\mathrm{I})$ thiolate $\left[\mathrm{Au}\left(\mathrm{SC}_{6} \mathrm{~F}_{5}\right)\right]_{n}{ }^{[63]}$. Attempts to synthesize complexes $\mathbf{3 a}, \mathbf{3} \mathbf{b}$ and $\mathbf{3 d}$ give similar results. This indicates that when the degree of fluorination of the phosphine increases, the gold center interacts with the lone pair of sulfur rather than with those of the phosphine, forming a more stable thiolate.

$\S$ Figure $\mathrm{S} 13$ in the ESI shows the barriers for dissociation of compounds 2, 3 and [AuCl(PPh3)]. Unfortunately, we were not able to compute the corresponding results for compound 1 or the
TS structure of the associative mechanism for a suitable comparison.

[1] S.-H. Shin, Bull. Korean Chem. Soc. 2005, 26, 1925-1926.

[2] C. Nieto-Oberhuber, M. P. Muñoz, S. López, E. JiménezNúñez, C. Nevado, E. Herrero-Gómez, M. Raducan, A. M. Echavarren, Chem. Eur. J. 2006, 12, 1677-1693.

[3] J. Y. Cheong, D. Im, M. Lee, W. Lim, Y. H. Rhee, J. Org. Chem. 2011, 76, 324-327.

[4] J.-E. Kang, H.-B. Kim, J.-W. Lee, S. Shin, Org. Lett. 2006, 8, 3537-3540.

[5] J. Schießl, J. Schulmeister, A. Doppiu, E. Wörner, M Rudolph, R. Karch, A. S. K. Hashmi, Adv. Synth. Catal. 2018 360, 2493-2502.

[6] A. C. Shaikh, D. S. Ranade, P. R. Rajamohanan, P. P. Kulkarni, N. T. Patil, Angew. Chem. Int. Ed. 2017, 56, 757761.

[7] J. Kim, W. Jeong, Y. H. Rhee, Org. Lett. 2017, 19, 242-245

[8] A. W. McCarter, M. Sommer, J. M. Percy, C. Jamieson, A. R. Kennedy, D. J. Hirst, J. Org. Chem. 2018, acs.joc.8b01121.

[9] J. S. Charlton, D. I. Nichols, J. Chem. Soc. A 1970, 0, 1484 1488.

[10] D. I. Nichols, J. Chem. Soc. A 1970, 0, 1216-1217.

[11] H. Schmidbaur, A. Schier, in Categ. 1, Organometallics (Ed.: O’Neil), Georg Thieme Verlag, Stuttgart, 2004, pp. 691-761.

[12] T. G. Appleton, H. C. Clark, L. E. Manzer, Coord. Chem. Rev. 1973, 10, 335-422.

[13] S. Boonseng, G. Roffe, R. Jones, G. Tizzard, S. Coles, J. Spencer, H. Cox, Inorganics 2016, 4, 25.

[14] A. O. Ogweno, S. O. Ojwach, M. P. Akerman, Dalt. Trans. 2014, 43, 1228-1237.

[15] H. Niu, R. J. Mangan, A. V Protchenko, N. Phillips, W. Unkrig, C. Friedmann, E. L. Kolychev, R. Tirfoin, J. Hicks, S. Aldridge, Dalt. Trans. 2018, 47, 7445-7455.

[16] M. Carmona, L. Tejedor, R. Rodríguez, V. Passarelli, F. J. Lahoz, P. García-Orduña, D. Carmona, Chem. Eur. J. 2017, 23, 14532-14546.

[17] D. Mendola, N. Saleh, N. Vanthuyne, C. Roussel, L. Toupet, F. Castiglione, T. Caronna, A. Mele, J. Crassous, Angew. Chem. Int. Ed. 2014, 53, 5786-5790.

[18] R. Cervantes, J. Tiburcio, H. Torrens, New J. Chem. 2015, 39, 631-638.

[19] L. Rocchigiani, J. Fernandez-Cestau, I. Chambrier, P. Hrobárik, M. Bochmann, J. Am. Chem. Soc. 2018, 140, 8287-8302.

[20] A. H. Greif, P. Hrobárik, M. Kaupp, Chem. Eur. J. 2017, 23, 9790-9803.

[21] A. Y. Sokolov, O. V Sizova, Russ. J. Gen. Chem. 2010, 80 1223-1231.

[22] L. Pazderski, in Annu. Reports NMR Spectrosc., Academic Press, 2013, pp. 33-179.

[23] J. Tong, S. Liu, S. Zhang, S. Z. Li, Spectrochim. Acta Part A Mol. Biomol. Spectrosc. 2007, 67, 837-846.

[24] S. P. C. Dunstan, P. C. Healy, A. N. Sobolev, E. R. T. Tiekink, 
A. H. White, M. L. Williams, J. Mol. Struct. 2014, 1072, 253 259.

[25] H. W. Chen, E. R. T. Tiekink, Acta Crystallogr. Sect. E Struct. Reports Online 2003, 59, m50-m52.

[26] L. Pauling, K. S. Pitzer, J. Am. Chem. Soc. 1960, 82, 4121 4121.

[27] R. H. Crabtree, The Organometallic Chemistry of the Transition Metals, Wiley-Interscience, New Jersey, 2005.

[28] M. C. Gimeno, A. Laguna, Chem. Rev. 1997, 97, 511-522.

[29] P. Sinha, A. K. Wilson, M. A. Omary, J. Am. Chem. Soc. 2005, 127, 12488-12489.

[30] D. Zuccaccia, L. Belpassi, A. Macchioni, F. Tarantelli, Eur. J. Inorg. Chem. 2013, 2013, 4121-4135.

[31] A. S. K. Hashmi, Angew. Chem. Int. Ed. 2008, 47, 6754 6756.

[32] D. Ding, T. Mou, M. Feng, X. Jiang, J. Am. Chem. Soc. 2016 138, 5218-5221.

[33] L. Biasiolo, A. Del Zotto, D. Zuccaccia, Organometallics 2015, 34, 1759-1765.

[34] D. Benitez, N. D. Shapiro, E. Tkatchouk, Y. Wang, W. A. Goddard, F. D. Toste, Nat. Chem. 2009, 1, 482-486.

[35] T. Mathieson, A. Schier, H. Schmidbaur, J. Chem. Soc. Dalt Trans. 2001, 1196-1200.

[36] J. P. Fackler Jr., B. E. Douglas, S. L. Holt Jr., J. H. Worrell, R. N. Grimes, R. J. Angelici, Inorganic Syntheses, John Wiley \& Sons, Inc., Hoboken, NJ, USA, 1990.

[37] E. Delgado, E. Hernandez, Polyhedron 1992, 11, 31353138.

[38] H. J. Emeléus, D. E. MacDuffie, J. Chem. Soc. 1961, O, 2572-2600.

[39] M. E. Peach, Can. J. Chem. 1968, 46, 2699-2706.

[40] E. Van Lenthe, E. J. Baerends, J. G. Snijders, J. Chem. Phys. 1993, 99, 4597-4610.

[41] C. van Wüllen, J. Chem. Phys. 1998, 109, 392-399.

[42] M. Levy, J. P. Perdew, J. Chem. Phys. 1986, 84, 4519-4523.

[43] A. D. Becke, Phys. Rev. A 1988, 38, 3098-3100.

[44] F. Weigend, R. Ahlrichs, Phys. Chem. Chem. Phys. 2005, 7, 3297.

[45] S. Grimme, S. Ehrlich, L. Goerigk, J. Comput. Chem. 2011
32, 1456-1465.

[46] S. Grimme, J. Antony, S. Ehrlich, H. Krieg, J. Chem. Phys. 2010, 132, 154104.

[47] O. Vahtras, J. Almlöf, M. W. Feyereisen, Chem. Phys. Lett. 1993, 213, 514-518.

[48] F. Neese, J. Comput. Chem. 2003, 24, 1740-1747.

[49] D. A. Pantazis, X.-Y. Chen, C. R. Landis, F. Neese, J. Chem. Theory Comput. 2008, 4, 908-919.

[50] V. Barone, M. Cossi, J. Phys. Chem. A 1998, 102, 19952001.

[51] J. L. Pascual-ahuir, E. Silla, I. Tuñon, J. Comput. Chem. 1994, 15, 1127-1138.

[52] E. Silla, I. Tuñón, J. L. Pascual-Ahuir, J. Comput. Chem. 1991, 12, 1077-1088.

[53] J. L. Pascual-Ahuir, E. Silla, J. Comput. Chem. 1990, 11, 1047-1060.

[54] F. Neese, Wiley Interdiscip. Rev. Comput. Mol. Sci. 2017, e1327.

[55] L. J. Farrugia, H. M. Senn, J. Phys. Chem. A 2010, 114, 13418-13433.

[56] L. J. Farrugia, C. Evans, H. M. Senn, M. M. Hänninen, R. Sillanpää, Organometallics 2012, 31, 2559-2570.

[57] L. C. Forfar, D. Zeng, M. Green, J. E. McGrady, C. A. Russell, Chem. Eur. J. 2016, 22, 5397-5403.

[58] G. Moreno-Alcántar, J. Manuel Guevara-Vela, R. DelgadilloRuíz, T. Rocha-Rinza, Á. Martín Pendás, M. Flores-Álamo, H. Torrens, New J. Chem. 2017, 41, 10537-10541.

[59] G. Moreno-Alcántar, K. Hess, J. M. Guevara-Vela, T. RochaRinza, Á. Martín Pendás, M. Flores-Álamo, H. Torrens, Dalt. Trans. 2017, 46, 12456-12465.

[60] R. F. W. Bader, Acc. Chem. Res. 1985, 18, 9-15.

[61] R. F. W. Bader, Atoms in Molecules: A Quantum Theory, Clarendon Press, 1990

[62] T. A. Keith, 2016, AIMAll (version 12.06.03) 2016.

[63] R. E. Bachman, S. A. . Bodolosky-Bettis, Zeitschrift für Naturforsch. B 2009, 64, 1491-1499. 


\section{Entry for the Table of Contents}

\section{FULL PAPER}

Experimental and theoretical examination of the influence of fluorination of the ligands on the stability and electronic structure of a series of gold $(I)$ compounds bearing fluorinated phosphines and thiolates.

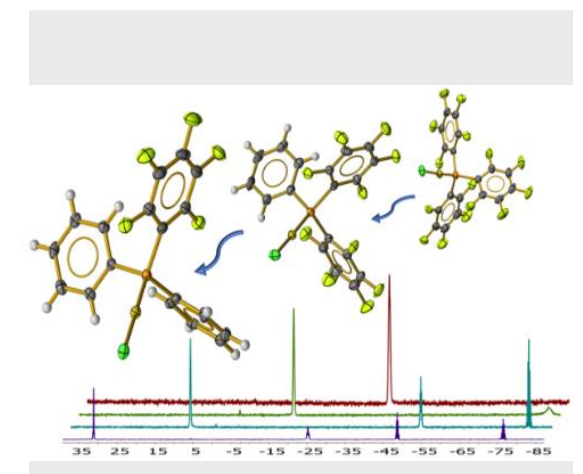

Trans influence and stability in gold compounds *

Guillermo Moreno-Alcántar*, Hugo

Hernández-Toledo,José Manuel Guevara-Vela, Tomás Rocha-Rinza, Ángel Martín Pendás, Marcos FloresÁlamo, and Hugo Torrens*.

Page No. - Page No.

Stability and trans influence in fluorinated gold(I) coordination compounds 